\title{
POLITICAL AND IDEOLOGICAL SOURCES OF THE POSITION OF PRESIDENT IN FRENCH FIFTH REPUBLIC
}

\section{ПОЛІТИЧНІ ТА ІДЕОЛОГІЧНІ ДЖЕРЕЛА ПОСАДИ ПРЕЗИДЕНТА У ФРАНЦУЗЬКІЙ П'ЯТІЙ РЕСПУБЛІЦІ}

\author{
Kucharčík Rudolf \\ Lecturer in International Political Relations, \\ Faculty of International Relations, Faculty of Economics \\ University of Bratislava
}

France is one of the leading state of the Europe. France is member of the European Union and many other international organizations. France has independent foreign policy. France is one of the most economically developed countries in the world. Sentiment of exceptionality has played remarkable role in French history.

Political and ideological sources of the position of president in French Fifth Republic are analyzed. The process of the creation of current French constitution are described. The term "patriotism" is described. The role and place of Charles de Gaulle in the development of the French Republic are described in the article. His attitude toward political parties and their influence on the political and social life of the state are analyzed.

Charles de Gaulle became prime minister in spring 1958 and he faces two challenges: to resolve the crisis in Algeria and to prepare a new constitutional text. Charles de Gaulle was the biggest authority in France in 1958 and it was not surprised that his proposal was accepted by French in referendum in September 1958. The Fifth republic was created. The form of the government created by the 1958 Constitution is a semi-presidential form of government. The presidential mandate was set on seven years. After referendum in 2000 - the length of the presidential mandate was shorten to five years. The de Gaulle itself embodied two traditions of French political history: the tradition of authority, order and stability and the tradition of the slogans of the French Revolution "Liberté, Egalité, Fraternité". Politics, political views of Charles de Gaulle and his position on the political development of the country are analized in the article.

The process of the creation of current French constitution was long-termed. It is the result of crisis of French Fourth republic and ideology of Gaullism, French nationalism and of course patriotism of Charles de Gaulle.

Key words: French President, Charles de Gaulle, French Constitution

Франція є однією з провідних держав у Європі. Франція є членом Європейського Союзу та багатьох інших міжнародних організацій. Франція проводить незалежну зовнішню політику. Франція є однією з найбільш економічно розвинених країн світу. Почуття винятковості відіграло неабияку роль у історії Франції.

В статті проаналізовано політичні та ідеологічні джерела посади президента у Французькій П'ятій республіці. Описано процес створення чинної французької конституції. В статті описано термін «патріотизм». Роль та місце Шарля де Голля у розвитку Французької республіки описано в статті. Проаналізовано його ставлення до політичних партій та їх вплив на політичне і суспільне життя держави.

Шарль де Голль став прем'єр-міністром навесні 1958 року, і перед ним стояли два виклики: вирішити кризу в Алжирі та підготувати новий конституційний текст. Шарль де Голль був найбільшим авторитетом у Франції в 1958 році, і не було дивним, що його пропозицію французи прийняли на референдумі у вересні 1958 року. П'яту республіку було створено. Форма правління, згідно з створеної Конституцією 1958 року, є напівпрезидентською фрормою правління. Мандат президента був встановлений на сім років. Після референдуму 2000 року - тривалість президентського мандату скоротилася до п'яти років. Шарль де Голль втілив дві традиції політичної історії Франції: традицію влади, порядку та стабільності та традицію гасел Французької революції “Liberté, Egalité, Fraternité". У статті проаналізовано політику, політичні погляди Шарля де Голля та його позицію щодо політичного розвитку країни.

Процес створення чинної французької конституції був довготривалим. Це результат кризи Французької четвертої республіки та ідеології голлізму, фрранцузького націоналізму і, звичайно, патріотизму Шарля де Голля.

Ключові слова: президент Франції, Шарль де Голль, фрранцузька конституція. 


\section{Introduction}

France is the leading state of the European Union and one of the regional powers with ambitious to be still world power.

Its power status stems from the following:

- a seat in the Security Council UN;

- ownership of nuclear weapons;

- member of the European Union;

- successful cultural diplomacy through Francophonie's involvement (presence) in its former colonies;

- independent foreign policy (withdrawal from the NATO military, blocking the entry of the United Kingdom into the European Communities, a critical assessment of the foreign policy of other superpowers);

- sentiment of exceptionality.

Sentiment of exceptionality has played remarkable role in French history.

According to Jacques Rupnik the aspect of this exceptionality is certainly related to the French Revolution form 1789. Three different moments were visible there - the moment of revolution, the moment of democracy and national moment. They were joined all. The following history has shown that the moment of revolution and the moment of democratic can be opposed. However, above-mentioned heritage shows us that analysis of processes of history is important to understand the source of French exceptionality.

French revolution with a universal message invented democracy and the declaration of Human Rights. That kind of perception of exceptionality and universality is unparalleled in Europe. The only analogy is found in the United States. This is one of the main reasons why the relationship between France and the US is so difficult [1, p. 185].

\section{Results}

The process of the creation of current French constitution was long-termed. The text is the result of crisis of French Fourth republic and ideology of Gaullism, French nationalism and of course patriotism of Charles de Gaulle and his political opinions.

Andrew Heywood talks about conservative nationalism in connection with Gaullism. According to him, this type of nationalism tends to develop in stabilized national states rather than in the states where the pro- cess of creating a national state has not yet been completed [2, p. 147].

The goal of this kind of nationalism was "maintaining national unity by promoting patriotism and pride in your state, especially against the disruptive ideas of class solidarity proclaimed by the socialists" $[2$, p. $147 ; 3]$.

According to Andrew Heywood, Charles de Gaulle was particularly successful to use nationalism for conservative goals.

De Gaulle referred to "national pride in guiding his independent and sometimes antiAmerican defense and foreign policy, which included French leaving of NATO. He has also tried to restore order and authority in social life and to build a strong state based on greater presidential powers. This policy has helped conservatives stay in power since the founding of the Fifth Republic until the election of Mitterand as president in 1981" [2, p. 147].

For political scientists is nationalism theoretical category - and it is one of the political ideologies. It is different for politicians the term "nationalism" has often negative connotations for them. Charles de Gaulle did not like it - he did not use this term to explain his position - he preferred the term patriotism.

Patriotism is "love for a homeland that is ready to stand in its defense ... often confuses itself to nationalism. Patriotism is a much older belief and it is not so much burdened with theory. Nationalism assumes that nations exist as real and distinctive entities. In contrast, patriotism can simply mean affection and a sense of connection to a particular place or way of life and does not require any abstract idea of "country" or fatherland. In fact, patriotism is a sentiment rather than a political idea. However, it can be used in the service of various beliefs, especially in the wars" [4, p. 344].

After the World War II Charles de Gaulle thought that new French constitution must significantly strengthen the president's powers.

According to him, the new constitution (the new Fourth republic constitution) should strengthen the role of the executive at the expense of parliament and political parties. The executive, and in particular the president, were to stand above the political parties and all social classes and represent the interests of France as a whole. 
His critical attitude toward political parties and their influence on the political and social life of the state was one of the main reasons for Charles de Gaulle's resignation in 1946. Governments in his view were dependent on the will of political parties and their leaders. The most important posts were not occupied on the basis of expertise but party affiliation. He formulated his position in the spring of 1946 as follows:

"France will never change. There will always be a revolutionary crowd on the left: Communists at this point. Then we always have a certain number of ideologists, cheaters and utopians who were still radical yesterday and today, they are socialists. There are still conservatives who consider themselves progressive... on the right side, where the crowd of Catholics, traditionalists, owners, industrialists and wholesalers meet... Finally, there is a swamp without faith and no law in the center... This is the main reason why the parties are not the solution... They bring only their exclusivity... Communists are trying to prevent the reaction and the right is trying to prevent Moscow's dictatorship" [5, p. 323].

The text of the Constitution prepared by the Constituent Assembly (and without Charles de Gaulle as he was not part of the political life anymore), dominated by Communists and Socialists, was rejected in a referendum in May 1946 (Figure 1).

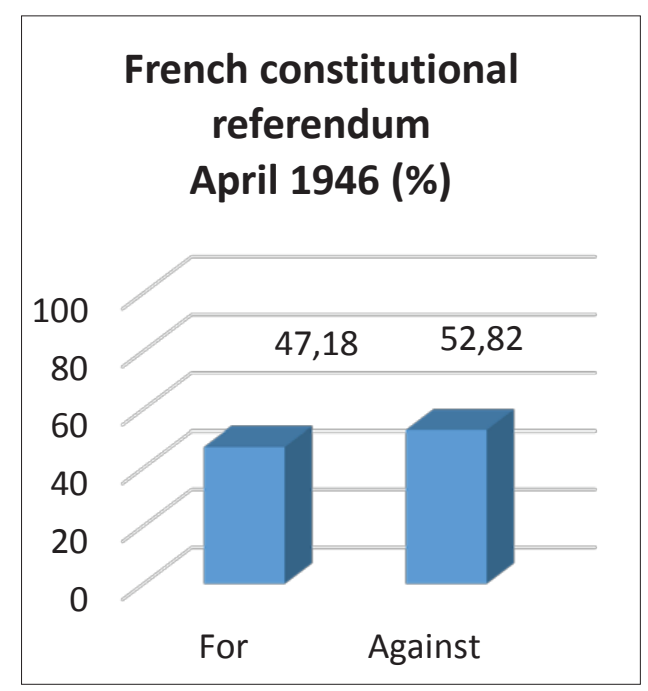

Fig. 1

Source: [6]
The newly elected Constituent Assembly, in which the left did not already have the majority, prepared a new text of the constitution, which was accepted by the French in a referendum in October 1946. Charles de Gaulle text of the new constitution rejected.

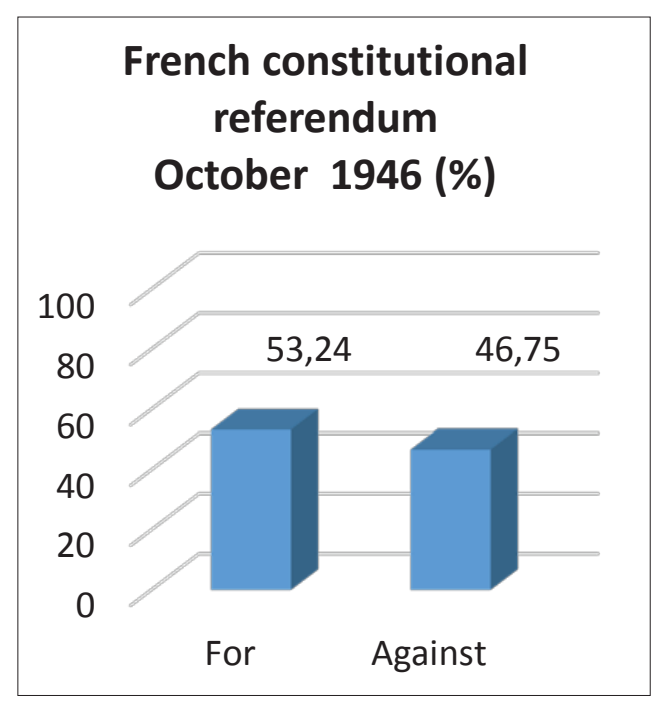

Fig. 2

Source: [7]

The question is whether Charles de Gaulle had already planned his return to politics in 1946. In his criticism of political parties, he went even further. Even he was prepared for the crisis of the Fourth republic and we know now that he was right - we can see it in these his words: "Nobody's planning anything, nobody's risking anything. Moreover, when the crisis comes, they will all be as little as they are in forties. So let us take care of just one: let us stay intact under the protection of my wings so that we can reappear when the danger goes away. That is why I will let them go down to the bottom. I have time. It is terrible, but we have to go through it. Only then, I will be able to present my terms" [5, p. 323].

The Fourth Republic is one of the most difficult and chaotic periods in French history. Unlike other European powers, France has faced two major events:

- the Cold War;

- decolonization.

Other European powers were not under such pressures.

- British and the Dutch were concerned only with decolonization; 
- Italians with only the processes associated with the Cold War;

- Germans neither or the other.

However, the French had to deal with the pressure of the USSR and Stalin on the one hand and the strong position of the French Communists, who, after 1947 (they were excluded from the government), de facto contributed to encouraging social unrest in the country, along with the gradual collapse of the colonial empire and the associated colonial wars including uprisings in colonies (Madagascar, Algeria, Indochina) [5, p. 322].

Inaddition, France was in apermanent political crisis. Only between 1946 and 1954 there were 20 different governments. By 1958, 7 others.

In this situation, most of the political leaders agreed that Charles de Gaulle could be the person who would bring the country out of the crisis (but not all of them the most influential opponent was François Mitterand).

Charles de Gaulle became prime minister with full power in spring 1958 .

He faces two challenges:

- to resolve the crisis in Algeria

- to prepare a new constitutional text.

Critics of the new French Constitution prepared by Charles de Gaulle highlighted two moments:

1. On the basis of the new constitution, France was transformed into an elected dictatorship.

2. The political system based on the constitution France could be transformed into new military dictatorship in the manner of Napoleon Bonaparte [8, p. 402].

The new constitution was based on political opinions and attitudes of Charles de Gaulle. According to the original idea of General de Gaulle, published in 1946 and repeated after 1958, the president should be an arbitrator in politics. It was then necessary to give him sufficient powers to be able to perform this function. The practice also has shown that powers written in constitution are not the source of all presidential power. Depending on the political situation, the powers of the president may be limited or extended" [9, p. 104].
Charles de Gaulle was the biggest authority in France in 1958. It was not surprised that his proposal was accepted by French in referendum in September 1958 (Figure 3). The Fifth republic was created.

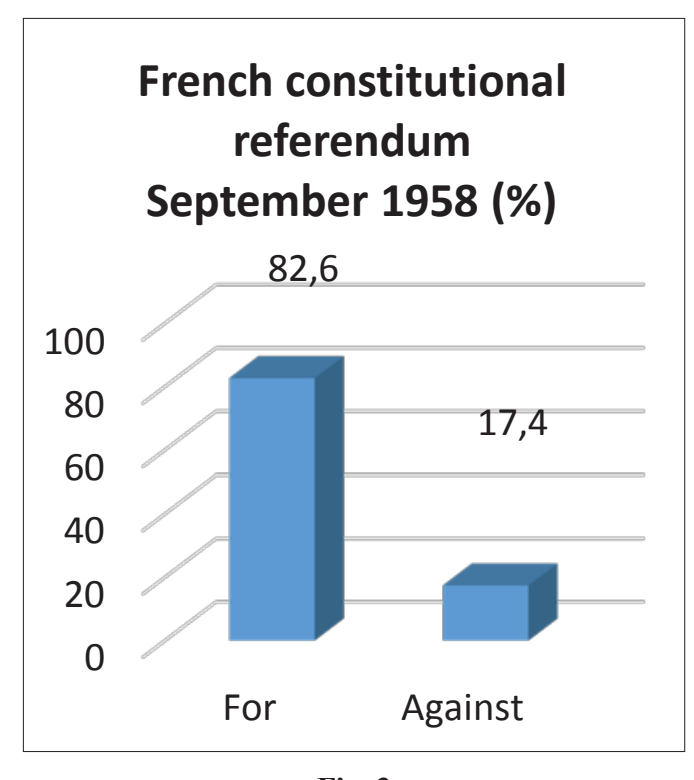

Source: [10]

The form of the government created by the 1958 Constitution is a semi-presidential form of government. In this case, the president (Head of State) and parliament are elected directly.

A specific characteristic is the strong position of the president, who has the right to dissolve parliament and at the same time to select the person who will chair the Government if the government is not chaired by him.

However, parliament has the right to give the government a lack of confidence.

At the same time, there is a permanent conflict between the prime minister and the president if the president and prime minister do not come from the same political party (or at least one of the parties forming a government coalition). The Fifth French Republic faced this situation (cohabitation) during the presidential mandate of Francois Mitterand (the prime minister was Jacques Chirac) and during the presidential mandate of Jacques Chirac (the prime minister was Lionel Jospin).

We can assume that Charles de Gaulle did not expect this situation (cohabitation). 
The prime minister was de facto accountable to the president (the result of party hierarchy). The political category of the semi-presidential system also did not correspond to France at the time of Charles de Gaulle's presidency in view of the real performance of the office for this period we can label it as the presidential form of government. However, this notion is not based on a vague written constitutional text, but on the performance of the post by Charles de Gaulle, which was characterized by the trespassing of the constitutional framework - the most of the political entities in the country, as well as the majority of French citizens, tolerated it until 1969.

What about the length of the presidential mandate it was set on seven years. "In 1958, the seven-year mandate was asserted as the traditional term of the head of state but it was mainly perceived as being long enough for the president to represent a certain continuity of the regime" [9, p. 104].

The situation changed after referendum in 2000 - the length of the presidential mandate was shorten to five years (the first president elected for five years was Jacques Chirac).

The most important change of the constitution was initiated by Charles de Gaulle - it was connected with the election of president of republic. Initially, the president of republic was elected indirectly - by special electoral board. The reason of Charles de Gaulle was clear - to weaken the role of political parties. Later he changed his mind - and in 1962 in referendum was approved new form of election of the president - direct. Of course, the 1965 presidential elections (the first under the new conditions) were closely watched.

For Charles de Gaulle himself, the 1965 presidential election was a surprise. General de Gaulle was sure of his position and popularity in France. For this reason too, he did not pay much attention to the electoral campaign. He and his team generally expected Charles de Gaulle to win the first round of the presidential election. In the first round, Charles de Gaulle did not gain an absolute majority, and only the second round, in which Chares de Gaulle defeated François Mitterand, decided the election.

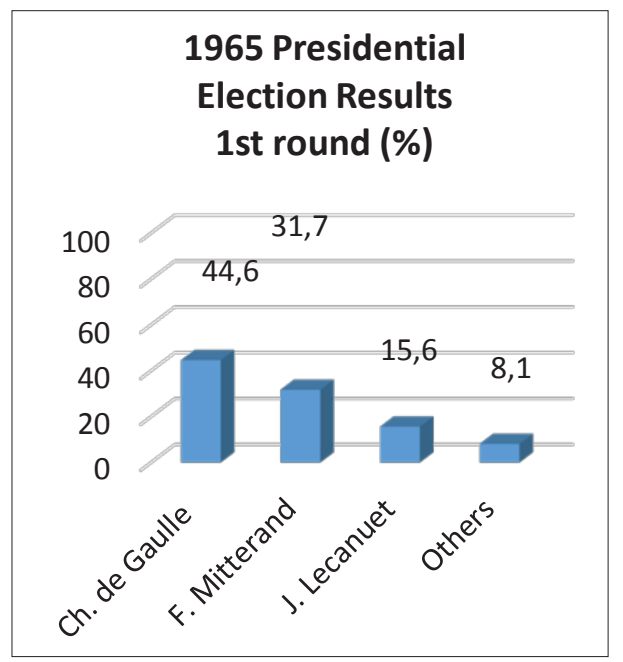

Figure 4

Source: [11]

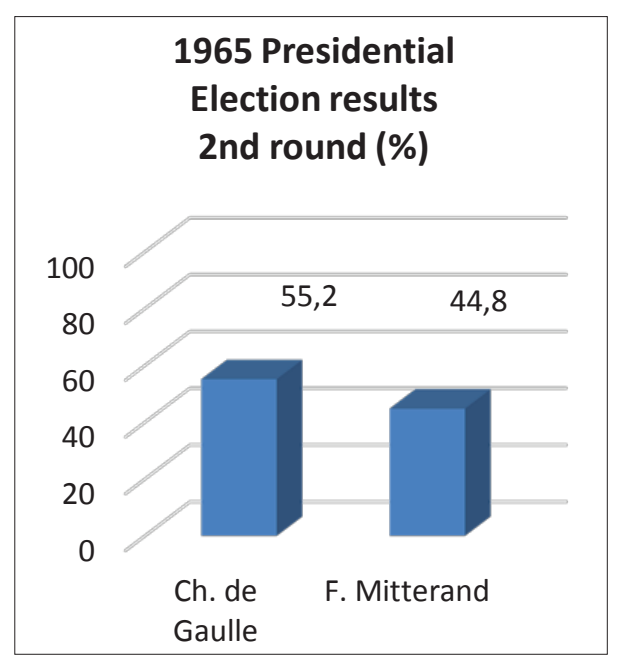

Figure 5

Source: [11]

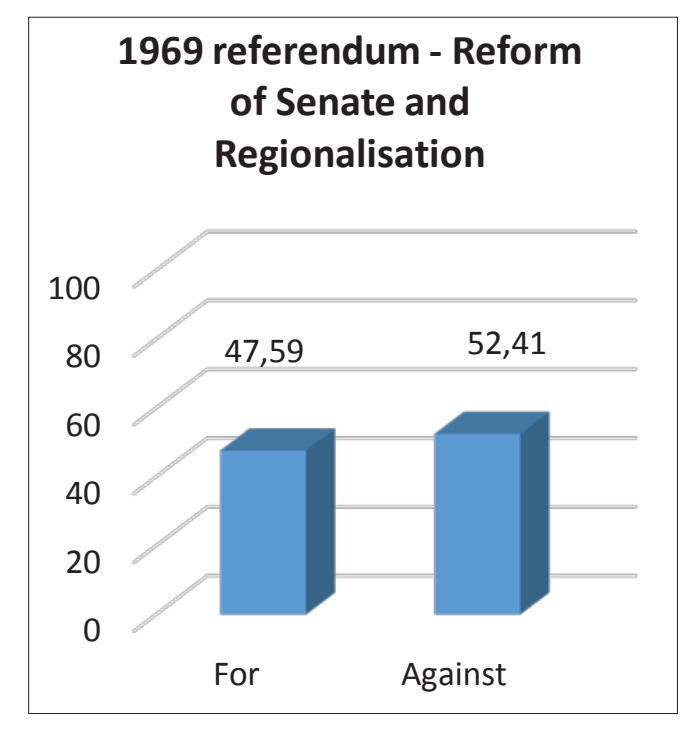

Figure 6

Source [12] 


\section{Conclusions}

Charles de Gaulle was convinced that he personified France and that his devoted followers would follow him. It is clear that he had several times rescued France and French democracy.

He was surprised by the events of 1968 in the country - and when he lost referendum in 1969 (Figure 6) he decided to retire.
The de Gaulle itself embodied two traditions of French political history:

1) the tradition of authority, order and stability as they were in the past represented by the monarch, the Catholic Church and the army

2) the tradition of the slogans of the French Revolution "Liberté, Egalité, Fraternité", which have claimed the legacy of the revolution but also the subsequent republican regimes $[8$, p. 401$]$.

\section{REFERENCES:}

1. Hvížd’ala, K. Př́liš brzy unavená demokracie : rozhovor s Karlem Hvížd’alou / Jaques Rupnik. Praha, Portál, 2009.

2. Heywood, A. Politické ideologie. Praha, Victoria Publishing, 1994. 300 s. ISBN 80-85865-10-6.

3. Heywood, A. Politologie. Plzeň, Vydavatelství a nakladatelství Aleš Čeněk, 2008.

4. Miller, D. et al. Blackwellova encyklopedie politického myšlení. Barrister \& Principal, 2003.

5. Ferro, M. Dějiny Francie. Praha : Nakladatelství Lidové noviny, 2006.

6. Référendum sur le projet de constitution du 19 avril 1946. [Electronic source]. Retrieved: https://mjp.univ-perp.fr/france/ref1946-5.htm

7. Référendum sur la Constitution de la Quatrième République [Electronic source]. Retrieved: http://mjp.univ-perp.fr/france/ref1946-10.htm

8. Sodaro, M., J. Comparative Politics. A Global Introduction. 2 vydanie. New York : McGraw-Hill.

9. Novák, M., Brunclík, M. Postavení hlavy státu v parlamentních a poloprezidentských režimech: Česká republika v komparativní perspektivě. Praha : Dokořán, 2008.

10. Constitution de la Ve République (1958). [Electronic source]. Retrieved: https:// www.france-politique.fr/referendum-1958.htm

11. Election Resources on the Internet: Presidential and Legislative Elections in France. [Electronic source]. Retrieved: http://electionresources.org/fr/president.php?election=1965

12. Participation (1969). [Electronic source]. Retrieved: https://www.france-politique.fr/ referendum-1969.htm 